Kharchuk Viktoriya, PhD (Economics), Associate Professor, Associate Professor of Management and International Business Department, Lviv Polytechnic National University, Lviv, Ukraine

ORCID ID: 0000-0003-4354-9549

e-mail: Viktoriia.Y.Kharchuk@lpnu.ua

Omelianchuk Anastasiya, Master Student Specialty «Management of Foreign Economic Activity», Lviv Polytechnic National University, Lviv, Ukraine

ORCID ID: 0000-0002-1074-6602

e-mail: anastasiia.omelianchuk.mnme.2019@lpnu.ua

\title{
Analysis of GRI and CSR Reports, submitted by Ukrainian Companies
}

\begin{abstract}
Introduction. The article investigates practical implementation of sustainable development and corporate social responsibility initiatives, based on GRI and CSR reports analysis.

Purpose. The aim of this study is to analyze SD and CSR reports and based on obtained results to make conclusions regarding practical implication highlighted concepts in Ukrainian business realities.

Results. Firstly, the authors elaborate an approach for analyzing given types of reports submitted by Ukrainian companies. Offered approach includes analysis of two separate samples (GRI and CSR reports) based on assessing 23 aspects which refer to SD and CSR initiatives. Secondly, main aspects and pieces of information, which are commonly used for describing SD and CSR in business practice are considered in detail and summarized.

Conclusions. Conclusions are made on the general comprehension of current practical implication of SD and CSR concepts, based on sequence of actions conducted by Ukrainian companies, highlighted in the reports.

Keywords: sustainable development; corporate social responsibility; reports; Ukrainian companies.
\end{abstract}

\section{удК 339.9}

Харчук В. Ю., кандидат економічних наук, доцент, доцент кафедри менеджменту та міжнародного підприємництва, Національний університет «Львівська політехніка», м. Львів, Україна

Омелянчук А. Б., здобувач вищої освіти ОКР «Магістр», Національний університет «Львівська політехніка», м. Львів, Україна

\section{Аналіз звітів GRI та КСB, поданих українськими компаніями}

Анотація. Беззаперечним є факт, що питання забезпечення гармонійного розвитку та корпоративної соціальної відповідальності є предметом дебатів як серед наукової спільноти, так і серед представників бізнесу. Одним із ключових моментів є проблематика практичної імплементації ініціатив даних концепцій вітчизняними суб'єктами господарювання.

Стаття спрямована на дослідження та аналіз особливостей відображення у звітах українських компаній, ініціатив та заходів із гармонійного розвитку та корпоративної соціальної відповідальності.

Запропоновано здійснювати дослідження двох вибірок одночасно: звітів, поданих до Глобальної ініціативи зі звітності (GRI), та звітів, поданих до бази даних CorporateRegister. Аналіз зазначених звітів здійснюється на підставі врахування двадцяти трьох аспектів, що всесторонньо описують концепції гармонійного розвитку та корпоративної соціальної відповідальності. Підставою для підтвердження наявності факту впровадження таких ініціатив на практиці $\epsilon$ детально сформульовані заходи, що мають матеріальну форму та опис яких наведений у звіті. Використовуючи такий підхід, стає можливим чітко окреслити аспекти, які набули практичного впровадження у виробничо-господарську діяльність на противагу лише задекларованим ініціативам.

На основі аналізу отриманої інформації авторами сформульовано узагальнення на предмет особливостей та упущень наявних у двох типів звітів, поданих вітчизняними підприємствами. На основі порівняльного аналізу отриманих результатів запропоновано висновки щодо загального стану практичної імплементації концепцій гармонійного розвитку та корпоративної соціальної відповідальності у практиці вітчизняних суб'єктів господарювання. Отримані результати будуть цікавими як для науковців, що займаються дослідженням означених концепцій, так і представникам бізнес-середовища, які активно займаються пошуком сучасних концепцій, спрямованих на підтримання багатовекторного та довгострокового розвитку.

Ключові слова: гармонійний розвиток; корпоративна соціальна відповідальність; звіти; украӥнські компанії.

Formulation of the problem. It is a wildly known fact that all companies in different areas of business are trying to reinforce their operations in order to maximize their profit, optimize resource consumption, and create trustworthy relationships with stakeholders. At the same time, operating in a fast-changing world demands 
business to seek and adopt different concepts aimed to achieve highlighted goals and maintain their development in general. Sustainable development (SD) and corporate social responsibility (CSR) are the most recognized ones, especially, when it comes to considering established international business experience.
Ukrainian companies are on the way to building responsible and transparent businesses, and have responded to those ideas by publishing reports on sustainable development and corporate social responsibility (table 1 ).

Table 1. Corporate sustainable reports (GRI) submitted by Ukrainian companies

\begin{tabular}{|c|c|c|c|c|c|c|c|c|c|c|c|}
\hline \multirow[b]{2}{*}{ Type } & \multicolumn{11}{|c|}{ Number of submitted reports per year respectively } \\
\hline & 옹 & 공 & ㄱ.ᅩ & $\stackrel{m}{\stackrel{n}{N}}$ & 굼 & 奋 & $\begin{array}{l}0 \\
-1 \\
\text { N }\end{array}$ & 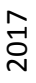 & $\stackrel{\infty}{-1}$ & 유 & ণ্ণ \\
\hline GRI-G4 & & & - & - & - & 4 & 4 & 3 & - & - & - \\
\hline Non-GRI & 3 & 5 & 6 & 3 & 4 & 5 & 5 & 4 & - & - & - \\
\hline Citing- GRI & - & - & 1 & - & 1 & - & - & - & - & - & - \\
\hline GRI-G3 & 2 & 2 & 4 & 8 & 3 & - & - & - & - & - & - \\
\hline $\begin{array}{l}\text { GRI- } \\
\text { Standards }\end{array}$ & - & - & - & - & - & - & - & - & 1 & 2 & 1 \\
\hline Total & 5 & 7 & 11 & 11 & 8 & 9 & 9 & 7 & 1 & 2 & 1 \\
\hline
\end{tabular}

Source: built by the authors according to [1-2]

Nevertheless, the results provided by Ukrainian companies are to be improved, especially in comparison with the achievements of companies from developed countries (fig. 1).

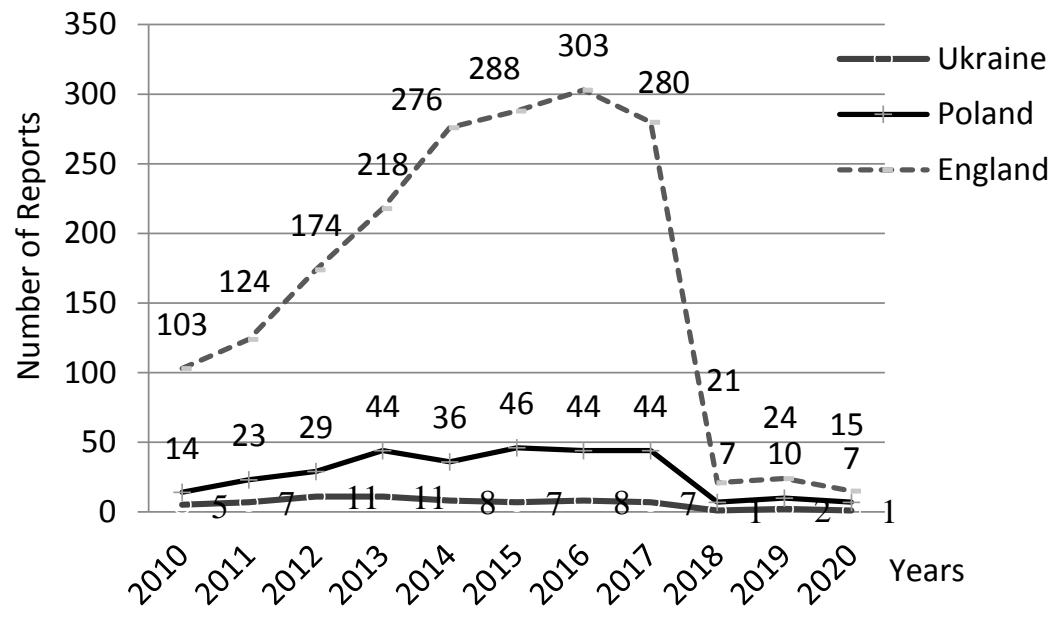

Figure 1 - The dynamic of GRI reports submitted by Ukrainian, Poland and British companies during the last decade

Source: built by the authors according to [1-2]

In order to get insights into practical implementation of SD and CSR concepts by Ukrainian companies we suggest analyzing the relevant reports.

Analysis of recent research and publications. CSR and SD theories have been a target of investigations since the previous century. The concept of CSR dates back to the mid XX century. In 1953, Bowen [3] initiated a discussion of responsibility connected with business activity, which turned into the concept of CSR.

John Elkington [4] offered a triplebottom-line approach (TBL) to SD theory, which considers sustainable development within three main dimensions such as harmonizing economic prosperity, environmental integrity and social equality [3]. Hill and Bowen (1997) [5] developed TBL to "four pillars" for SD (social, economic, biophysical and technical dimensions).

There is a number of theoretical views on the essence of CSR in the works by internationally recognized scholars such as Carol [6], Bowen [3], Davis [7], Levitt [8], E. Freeman [9] as justification for the need of responsible business before society and the surrounding environment.

Carol [6, p. 268] defined CSR as a theoretical "core" in building a SD strategy, Bowen [3] as an obligation for 
entrepreneurs to implement the policy and managerial decisions, and make them a priority given the ethical values and development goals of the entire society.

At the same time the study of given problem in the Ukrainian scientific literature was carried out mainly in the context of social and environmental issues analysis in the works of: Trehobchuk [10], Sokhatskaya [11], Bitsura [12], Zgurovsky [13], Korniychuk [14] and other. In today's Ukrainian business practice, authors [10-14] who investigate this topic use such terms as ethical practices, environmental protection, and transparency of actions, consideration of all parties involved, responsibility, responsible behavior, moral obligations, corporate social responsibility or corporate citizenship.

Today, the most internationally recognized definitions of CSR and SD are the ones suggested by the World Commission on Environment and Development in 1987 [15]. The stressed the necessity of harmonizing the needs of the current generation as well as future needs. There CSR is defined as a long-term commitment of companies to conduct business ethically and to promote the sustainable economic development of businesses, the community and society at large.

According to the results of the Socially Responsible Business Forum, CSR is defined as responsible attitude of a company to its product or service, consumers, employees, partners, active social position of the company that is, harmonious coexistence, interaction with society and participation in solving acute social problems [16].

To sum up, international studies [3-9] focus on the multifaceted dimension of SD and CSR concepts, in order to achieve continuous development, and pointing out the necessity to consider all components (TBL idea). Whereas the Ukrainian researches [10-14] tend to emphasize these categories unilaterally, outlining only some components.

Formulation of research goals. The aim of this study is to investigate practical implication of SD and CSR ideas in Ukrainian business realities. With this in mind, we suggest analyzing official GRI and CSR reports, submitted by Ukrainian companies for the last two decades. The main idea is to analyze the content of a given reports in order to:

1) determine aspects, that might be considered as "SD initiatives" and "CSR initiatives" presented in submitted reports;

2) investigate general attitude of the companies towards SD and CSR concepts;

3) trace the development of "SD initiatives" and "CSR initiatives" presented in the reports, submitted by companies on a regular basis;

4) summarize the aspects and information, commonly used for describing SD and CSR in business practice;

5) make a general comprehension of current practical implication of SD and CSR concepts, based on sequence of actions conducted by Ukrainian companies, highlighted in the reports.

Outline of the main research material. It is common knowledge that making non-financial reports is voluntary and helps to build both responsible business and trustful relationship with stakeholders. Practical application of SD and CSR ideas in Ukrainian companies might be analyzed via non-financial reporting.

We argue that description of particular activity, presented in the report, might be considered as practical implication of SD or CSR ideas only when it has clear comprehensive description and tangible form (e.g. policy, code of conduct, questionnaire, project, equipment, methodology, technical and technological enhancement etc.). As a result, we decide to create and investigate two samples separately:

1) all reports submitted to the Global Reporting Initiative (GRI) [1] by Ukrainian companies for 2010 - 2020 (as of July 2020). This sample includes 71 reports submitted by 16 companies;

2) all CSR reports available on Corporategister [17] platform for 2007 - 2018 (as of August 2020). In this case, sample includes 71 reports submitted by 11 companies.

The databases were selected on the basis of GRI[1] and Corporategister [17] recognition and availability of full reports throughout.

Based on literature review [6-14] on generally accepted elements of SD and CSR practices and aspects that have to be highlighted in the report, according to Global Reporting Initiative [1] we selected the aspects, which enables to argue about companies perception of the given practices. As a result, we have obtained 23 aspects that will be applied for the analysis of Ukrainian reports. All the reports were reviewed by two authors independently to make unbiased conclusions regarding presented information. The results of reports analysis are presented in Tables 2-3.

The analysis of the CSR reports yielded the following comments:

- as judged by descriptions of corporate responsibility, presented in the reports, we may state that Ukrainian companies pay the most significant attention to social projects and charity, describing them in details in each report;

- all reports focus mostly on social aspects, namely employee engagement, including professional development and career planning (e.g. DTEK Academy, INSEAD business school (France), IE Business School (Spain), SoftServe Coaching program); employee health (e.g. Ernst\&Young provides medical insurance and organize Health Days); ethics and professional conduct culture (e.g. Code of Ethics and Professional Conduct formed by Deloitte);

- the vast majority of CSR reports reflect the detailed information regarding environmental protection initiatives (such companies as Infopulse, Coca-Cola, Ernst\&Young, ArcelorMittal, DTEK give Eco-Management Statistics for the period of last 2 years and show how the consumption of each resource is changed);

- it is also worth noting that companies focus on compliance with standards and certification (e.g. Avalon, Infopulse, DTEK). 
- the least attention in the analyzed reports is paid to the peculiarities of operating and investment activities, management systems, distribution of rights and responsibilities among staff;

- to sum up, very few Ukrainian companies actually have a thorough and structured corporate social responsibility reports that contain detailed information supported by calculations and indicators. Mostly, in their CSR reports companies describe only general aspects of their activity, which are not supported by any evidence.

Table 2. Comparative analysis of aspects, included in GRI reporting on sustainable development conducted by Ukrainian companies*

\begin{tabular}{|c|c|c|c|c|c|c|c|c|c|c|c|c|c|c|c|c|c|}
\hline $\begin{array}{l}\text { № } \\
3 / \Pi\end{array}$ & $\begin{array}{l}\text { Aspects reflected in the } \\
\text { reporting }\end{array}$ & 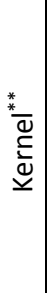 & 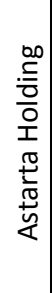 & 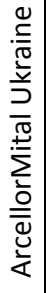 & 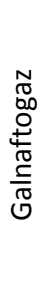 & 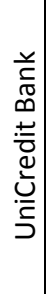 & 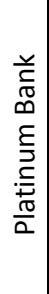 & 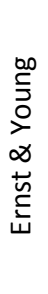 & 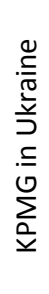 & 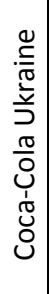 & $\begin{array}{l}\frac{5}{0} \\
\frac{0}{0}\end{array}$ & 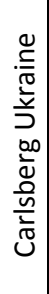 & $\frac{2}{\frac{1}{2}}$ & 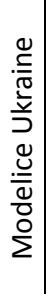 & 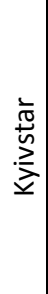 & 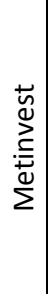 & 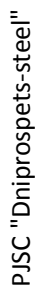 \\
\hline 1 & Financial results & + & + & - & + & - & + & + & - & - & + & - & - & - & - & + & + \\
\hline 2 & Features of operating activities & + & + & + & + & - & + & + & - & - & + & - & + & - & - & + & - \\
\hline 3 & Investment policy/strategy & + & - & - & - & + & - & - & - & - & - & - & - & - & - & + & + \\
\hline 4 & Interaction with stakeholders & + & + & + & + & + & + & + & + & - & + & - & + & - & - & + & + \\
\hline 5 & Electricity consumption & + & + & + & - & - & + & + & + & + & + & + & - & + & + & + & + \\
\hline 6 & Biodiversity & + & + & - & - & - & - & - & - & + & - & + & - & - & - & - & - \\
\hline 7 & $\begin{array}{l}\text { Atmospheric emissions } \\
\text { (including air purification) }\end{array}$ & - & + & + & - & - & - & + & + & & + & + & - & + & - & + & + \\
\hline 8 & $\begin{array}{l}\text { Waste management and } \\
\text { disposal }\end{array}$ & + & + & + & + & - & + & - & + & + & + & - & + & + & - & + & + \\
\hline 9 & Raw materials & - & + & + & + & - & + & + & + & + & + & + & - & + & - & - & - \\
\hline & Water usage & - & + & + & - & - & - & - & + & + & + & + & - & + & - & + & + \\
\hline 10 & Product safety & + & - & + & - & - & - & - & - & + & + & + & - & + & - & - & - \\
\hline 11 & Safe working conditions & + & + & + & + & - & - & - & - & - & + & + & + & + & - & + & + \\
\hline 12 & $\begin{array}{l}\text { Professional development and } \\
\text { career planning }\end{array}$ & + & + & + & + & + & + & + & + & + & + & + & + & + & - & + & + \\
\hline 13 & Employee health & + & + & + & + & + & + & + & - & + & + & - & + & + & - & + & + \\
\hline 14 & $\begin{array}{l}\text { Material incentives for } \\
\text { employees } \\
\text { compensation and benefits) }\end{array}$ & + & + & - & + & - & + & - & + & - & + & + & + & + & - & + & + \\
\hline 15 & Features of management & + & + & + & + & - & + & - & + & - & - & - & + & - & - & + & + \\
\hline 16 & $\begin{array}{l}\text { Distribution of rights, } \\
\text { responsibilities of leaders, their } \\
\text { gender and age structure, etc. }\end{array}$ & + & + & - & - & - & + & - & + & - & - & - & - & - & - & + & + \\
\hline 17 & Prevention of corruption & + & + & + & - & + & + & - & + & - & + & - & + & - & - & - & + \\
\hline 18 & Protection of human rights & + & - & - & - & + & - & - & - & + & + & + & + & - & - & + & - \\
\hline 19 & Conflict resolution & + & - & - & - & - & + & - & - & - & - & - & - & - & - & + & - \\
\hline 20 & $\begin{array}{l}\text { Values, principles and norms of } \\
\text { ethical business conduct } \\
\text { (including employees) }\end{array}$ & + & + & - & - & + & + & + & - & - & + & + & - & - & - & - & - \\
\hline 21 & $\begin{array}{l}\text { Corporate culture (including } \\
\text { product consumption culture) }\end{array}$ & - & - & - & + & + & - & - & - & - & + & + & + & - & - & - & - \\
\hline 22 & $\begin{array}{l}\text { Compliance with standards and } \\
\text { certification }\end{array}$ & + & + & + & - & - & - & - & - & - & + & + & + & + & - & + & + \\
\hline 23 & Social projects/charity & + & + & + & + & + & + & + & + & + & + & + & + & + & + & + & + \\
\hline
\end{tabular}

* - formed by the author on the basis of reports submitted to [17] and the list of companies placed on [18]

** - the names of the companies are displayed according to their names given in the reports

Conclusion. Based on obtained results we have made the following implication regarding the practical implementation SD and CSR initiatives in the researched companies:
- companies define SD and CSR in myriad ways, which leads to taking different actions and different focuses in practice;

- companies equate SD and CSR, which in some cases leads to focusing mostly on social aspects; 
- relatively stable tendency to expand the practice of adopting SD and CSR ideas in the Ukrainian business;

- vast majority of companies, which submitted GRI reports are counterparts of international corporations (e.g. UniCredit Bank in Ukraine, Ernst \& Young in Ukraine, KPMG in Ukraine, Coca-Cola Ukraine, Carlsberg Ukraine, Mondelēz Ukraine);

- we assume that originally Ukrainian companies, which submitted GRI reports on a regular basis (Astarta, Kernel, ArcelorMittal) intend to be more visible on international markets, attract more partners worldwide, reassure stakeholders on their desire to develop in different areas and prove to be responsible business models;
- in some cases described initiatives resemble a simple formality in order to reinforce brand image and hard to conclude whether companies adhere to decelerated principles of responsible business;

- generally, companies appear to be focused on sustainability-related actions or CSR initiatives that might have a direct impact on their business performance.

The findings of the study might contribute to the theoretical debate on SD and CSR initiatives adoption by business entities. Obtained results might be beneficial to distinguishing shortcuts that impede the adoption SD and CSR initiatives by Ukrainian companies.

\section{References:}

1. Global Reporting Initiative (GRI) (2020). Official web-site. Retrieved from http://database.globalreporting.org/search

2. List of GRI Standards reports and published materials with their self-declared claims (2020). Official web-site. Retrieved from https://www.globalreporting.org/reportregistration/verifiedreports.

3. Bowen, H. (1953). Social Responsibility of the Businessman. N.Y.: Harper \& Row.

4. Elkington, J. B. (2007). Cannibals with Forks: The Triple Bottom Line of 21st Century Business. Environmental Quality Management, 1, 37-51.

5. Hill, R. C. and Bowen, P. A. (1998). Sustainable construction: principles and a framework for attainment. Construction Management and Economics, 3, 223-239.

6. Carroll, A.B. (1999). Corporate social responsibility: Evolution of definitional construct. Business and Society, 38 (3), $268-295$.

7. Davis, K. (1960). Can business afford to ignore social responsibilities. California Management Review, 2 (3), 70-76.

8. Levitt, T. (1958). The Dangers of Social Responsibility. Harvard Business Review, 5, 41-50.

9. Freeman, R. E. (1984). Strategic Management. A Stakeholder Approach. Boston, Pitman Publishing Inc.

10. Treghobchuk, V. (2002). The concept of sustainable development for Ukraine. Visnyk NAN Ukrajiny, 2, 48-52 [in Ukrainian].

11. Sokhacjka, O. M. (2006). Formation of a new paradigm of corporate governance in the global environment. Visnyk Ternopiljsjkogho derzhavnogho ekonomichnogho universytetu, 3, 24-40 [in Ukrainian].

12. Bycjura, Ju. (2006). To the problem of defining the concepts of sustainable economic growth and development. Ekonomist, 9, 62-70 [in Ukrainian].

13. Zghurovskyj, M. Z., Ghvyshyany, A. D. (2008). Ghlobaljnoe modelyrovanye processov ustojchyvogho razvytyja v kontekste kachestva y bezopasnosty zhyzny cheloveka. K.: NTUU "KPY" "Polytekhnyka" [in Russian].

14. Kornijchuk, L. (2008). Economic growth and sustainable development. Ekonomika Ukrajiny. 3, 84-92 [in Ukrainian]

15. The World Council of SD Companies (2020). Official web-site. Retrieved from https://www.wbcsd.org.

16. Socialjna vidpovidaljnistj biznesu: pryncypy systemnoji diji. (2006). Zvit Forumu socialjno vidpovidaljnogho biznesu Ukrajiny. Kyiv, 22 [in Ukrainian].

17. Corporate Register (2020). Official web-site. Retrieved from https://www.corporateregister.com.

18. CSR in Ukraine (2020). Official web-site. Retrieved from https://csr-ukraine.org/pro-nas/\#members [in Ukrainian]. 